\title{
Pollution Status of Heavy Metals in Surface Sediments Collected from West Coast of Peninsular Malaysia
}

\author{
Tijjani Rufa'i Buhari ${ }^{1,2 *}$, Ahmad Ismail ${ }^{1}$ \\ ${ }^{1}$ Department of Biology, Faculty of Science, University Putra Malaysia, Serdang, Malaysia \\ ${ }^{2}$ Department of Biological Science, Yusuf Maitama Sule University, Kano, Nigeria \\ Email: *trbuhari@yahoo.com
}

How to cite this paper: Buhari, T.R. and Ismail, A. (2020) Pollution Status of Heavy Metals in Surface Sediments Collected from West Coast of Peninsular Malaysia. Open Access Library Journal, 7: e6829. https://doi.org/10.4236/oalib.1106829

Received: September 16, 2020

Accepted: October 16, 2020

Published: October 19, 2020

Copyright $\odot 2020$ by author(s) and Open Access Library Inc.

This work is licensed under the Creative Commons Attribution International License (CC BY 4.0).

http://creativecommons.org/licenses/by/4.0/

\begin{abstract}
The present study examined status of heavy metals $(\mathrm{Cu}, \mathrm{Zn}, \mathrm{Pb}, \mathrm{Cd}$ and $\mathrm{Ni})$ pollution in the surface sediments of west coast of Peninsular Malaysia. Heavy metals concentrations were determined by using air acetylene flame atomic absorption spectrophotometer (AAS) Perkin Elmer Analyst 800. The results of particle size analysis of the surface sediments indicate high metals concentrations at sampling sites with high content of sand and clay particles. The results of Pearson's correlation analysis based on the relationship between particle size distribution and total heavy metals, and the relationship between the studied metals $(\mathrm{Cu}, \mathrm{Zn}, \mathrm{Pb}, \mathrm{Cd}$ and $\mathrm{Ni}$ ) revealed significant correlations at $(\mathrm{p}<0.05$ or $\mathrm{p}<0.01)$ except few cases were non-significant correlations were observed. The Igeo values ranged between Igeo class 1 (unpolluted to moderately polluted) to Igeo class 5 (strongly to very strongly polluted) and the $\mathrm{EF}$ of no enrichment $(\mathrm{EF}<1)$ to severe enrichment $(\mathrm{EF}=10$ 25) depending on the sampling sites and the heavy metal. Lead showed the highest Igeo values at all the sampling sites with exception of Bg. Lalang (class $1)$ and $(\mathrm{EF}=10-25)$ at two sampling sites which might suggest the metal was significantly impacted by anthropogenic sources at the sampling sites. The pollution load index (PLI) indicates strong signs of pollution deterioration by the studied metals at all the sampling sites. The order of sampling sites from highest to lowest PLI values was; $2>5>3>1>6>4$. The Igeo, EF and PLI values indicate heavy metals contamination in the study area, particularly $\mathrm{Pb}$. Considerable attention should be made at sampling sites that showed higher metals contamination in order to monitor metals pollution and save its biological components from deterioration.
\end{abstract}

\section{Subject Areas}

Environmental Sciences 


\section{Keywords}

Heavy Metals, Surface Sediments, Pollution Indices, West Coast of Peninsular Malaysia

\section{Introduction}

The continuous discharge of heavy metals into the coastal environment has attracted global attention and concern due to their toxicity, persistent and accumulation in sediment and living organisms. Sediments act as a sink of organic as well as inorganic pollutants (heavy metals) and provide a history of anthropogenic pollutant input [1] and environmental changes [2].

The pollution status of marine sediments has often been used as an important criterion to evaluate the condition of coastal environment and to understand the possible environmental changes caused by anthropogenic activities [3]. Generally, in unpolluted environment most of the heavy metals are in low levels. However, high metal concentrations in sediment do not automatically imply that contamination has occurred, but may simply reflect the natural mineralogical composition of the parent geological material and the grain size and organic matter content of the host sediment [4]. Naturally occurring elements as a result of pedogenesis are rarely noxious and are present in trace concentrations [5]. Heavy metals and related pollutants released from agricultural, industrial and domestic activities, ports, shipping boating and recreational use of water bodies, land-reclamation, tourism, chemical spills, sewage treatment plants, leaching from domestic garbage dumps and mining tend to accumulate in water, sediments and biota. Pollution of the natural environment by heavy metals is a worldwide problem as these metals are indestructible and have toxic effects on living organisms when they exceed a certain concentration limit [6].

Coastal ecosystems are among the most valuable on earth due to their provisioning of ecosystem services [7] [8]. Despite their value, coastal ecosystems are being rapidly degraded globally by human activities [9] [10] [11] such as eutrophication, toxic substances, heavy metals, acidification and siltation [12], which might have accelerated damage to the coast [13]. In coastal ecosystem, metals exist in either dissolved state in the water column or get deposited on the sediment bed, depending upon the nature of the chemical species and physicochemical factors like $\mathrm{pH}$, conductivity, salinity and organic matter [14] [15] [16]. Despite different sources of heavy metals, the coastal and marine sediments are considered as the main fate for heavy metals presence in aquatic systems [17].

Research efforts have focused on coastal environments since these highly productive and sensitive areas are often directly and most seriously affected and exposed to this problem because of their proximity to sources of pollution [18] [19] from industries, shipping, agriculture domestic and other related activities. Heavy metals are regarded as a main anthropogenic pollutant in coastal and ma- 
rine environments globally [20]. The enrichment of coastal environments with anthropogenic contaminants particularly heavy metals remains a topic of discussion in ecotoxicology. Several researches on heavy metals contamination in the coastal environments were reported from different part of the world by many authors; [21] [22] [23] [24] [25].

Recently, great development has occurred around Malaysia, especially Peninsular Malaysia as industrialization, urbanization, the advancement of agriculture and other activities related to the modern era are occurring rapidly, which have directly influenced the coastal ecosystems that contain aquatic resources, for example, fish, which are also used by humans [26]. The significant and benefit of the west coast of Peninsular Malaysia can not to be overemphasized as such many studies on distribution, enrichment and accumulation of heavy metals in the sediment of this area were reported by [27] and [28]. The present study was aimed to assess pollution status of heavy metal $(\mathrm{Cu}, \mathrm{Zn}, \mathrm{Pb}, \mathrm{Cd}$, and $\mathrm{Ni})$ in the surface sediments of some selected areas in the west coast of Peninsular Malaysia using Igeo, EF and PLI indices.

\section{Materials and Methods}

\subsection{Study Area}

Samplings were conducted in August 2008 to June 2010. A total of six sampling sites were selected for surface sediments in the west coast of Peninsular Malaysia (Figure 1). The sampling sites were chosen based on the past researches and human activities in the selected sampling sites in order to justify the status of heavy metals in the surface sediment and look for possibility of low or high metals input. The coordinates of sampling sites were recorded with Global positioning system (Garmin OREGON 45OT $850 \mathrm{MB}$ waterproof GPS). Description of each sampling site was given in Table 1 .

\subsection{Sample Preparation and Acid Digestion}

Surface sediment were collected in triplicate from top $3-5 \mathrm{~cm} \mathrm{[29]} \mathrm{[30]} \mathrm{at} \mathrm{each}$ sampling site (Figure 1), using plastic scoop and placed in separate labelled polyethylene plastic bags. Each sediment sample was instantly placed in ice and transported to the laboratory until further analysis.

Table 1. Description of sampling sites in the west coast of Peninsular Malaysia.

\begin{tabular}{|c|c|c|c|}
\hline No. & Sampling sites & Coordinates & Site description \\
\hline 1. & S. Garam & $\mathrm{N} 05^{\circ} 39.552^{\prime} \mathrm{E} 100^{\circ} 23.983^{\prime}$ & Jetty, aqua cultural area and paddy field \\
\hline 2. & K. Juru & $\mathrm{N}^{\circ} 5^{\circ} 19.683^{\prime} \mathrm{E} 100^{\circ} 22.949^{\prime}$ & Industrial area, urbanization and aquaculture \\
\hline 3. & Sg. Puluh & N03 ${ }^{\circ} 04.786^{\prime} \mathrm{E} 101^{\circ} 23.903^{\prime}$ & Jetty receiving domestic wastes and industrial area \\
\hline 4. & Bg. Lalang & $\mathrm{N} 02^{\circ} 36.669^{\prime} \mathrm{E} 101^{\circ} 41.100^{\prime}$ & Recreational and agricultural areas \\
\hline 5. & M. Beku & $\mathrm{N}^{\circ} 1^{\circ} 47.746^{\prime} \mathrm{E} 102^{\circ} 53.395^{\prime}$ & Jetty receiving domestic wastes and shipping activities \\
\hline 6. & Sg. Tiga & $\mathrm{N} 01^{\circ} 25.841^{\prime} \mathrm{E} 104^{\circ} 00.281^{\prime}$ & Jetty, agricultural and oil plantation \\
\hline
\end{tabular}






Figure 1. Map of west of Peninsular Malaysia showing six sampling sites (1, 2, 3, 4, 5 and 6).

Sediment samples were dried in the laboratory using an air-circulating oven to a constant dry weight at $80^{\circ} \mathrm{C}$. The dried sediment samples were crushed to powder by using a porcelain mortar and pestle then sieved vigorously to produce homogeneity [29], through a $63 \mu \mathrm{m}$ stainless steel aperture sieve. For analyses of total heavy metals concentrations $(\mathrm{Cu}, \mathrm{Zn}, \mathrm{Pb}, \mathrm{Cd}$ and $\mathrm{Ni})$ in the sediment sample, direct aqua-regia method was employed as described by [29].

All samples were placed in a hot block digester at low temperature $\left(40^{\circ} \mathrm{C}\right)$ for $1 \mathrm{~h}$ and were then fully digested at high temperature $\left(140^{\circ} \mathrm{C}\right)$ for $3 \mathrm{~h}$. The digested samples were diluted to a volume of $40 \mathrm{~mL}$ using double distilled water (DDW). The samples were filtered using Whatman No.1filter paper and the filtrate was stored in a refrigerator $\left(4^{\circ} \mathrm{C}\right)$ until metal determination. After filtration, the prepared samples were determined for $\mathrm{Cu}, \mathrm{Zn}, \mathrm{Pb}, \mathrm{Cd}$ and $\mathrm{Ni}$ using an air-acetylene flame Atomic Spectrophotometer (AAS) Perkin-Elmer Model A Analyst 800 . The data were presented in $\mu \mathrm{g} / \mathrm{g}$ dry weight.

During the period of AAS metal analysis, a quality control sample was routinely included for every 5 - 10 samples. Procedural blanks and quality control samples made from standard solutions for $\mathrm{Cu}, \mathrm{Zn}, \mathrm{Pb}, \mathrm{Cd}$ and $\mathrm{Ni}$ were analysed after every 5 - 10 samples to ensure the sensitivity and recovery of the instrument used. The procedures of quality assurance (QA) and quality control (QC) were employed to ensure the validity of the analytical data [31]. All plastics and 
glassware used were washed with detergent, Deacon 90, rinsed with double-distilled water and soaked in $10 \% \mathrm{HNO}_{3}$ for at least $24 \mathrm{~h}$, then rinsed with double-distilled water and allowed to dry at room temperature. The QA and QC were controlled by procedural blanks, sample replicates and certified reference material (CRM). The quality of the method was checked with a certified reference material (CRM) for Soil from International Atomic Energy Agency (IAEA), Soil-5, Vienna; Austria and Dogfish liver DOLT-3 from National Research Council Canada (NRCC) were analysed. These were checked to accuracy of the digestion method with the certified values supplied by the IAEA and NRCC. To ensure the sensitivity of the Atomic Absorption Spectrophotometer (AAS) and generate calibration curves against which sample concentrations were calculated. The results of similar digested samples analysed for $\mathrm{Cu}, \mathrm{Zn}, \mathrm{Pb}, \mathrm{Cd}$ and $\mathrm{Ni}$ by the flame AAS Perkin Elmer A Analyst 800 showed acceptable recoveries of the metals. About $94 \%-107 \%$ for soil and $87-110$ for dogfish liver, recoveries of these metals were listed in Table 2. The percentages of recoveries for the heavy metal analyses were $97 \%$ - 107\% (Table 2).

\subsection{Surface Sediments Analyses}

\subsubsection{Particle Size Analysis}

Particle size analysis is the measurement of the size of individual particles in the soil/sediment. Particle-size analysis of sediment samples was performed by pipette method following the procedure of [32]. The percentage of clay, silt and sand was classified by using United States Department of Agriculture (USDA) sediments classification scheme [33].

\subsubsection{Assessment of Metals Contamination}

Metals concentrations were calculated using world average shale [34] and lowest concentration in the present study as background concentrations (Table 3).

Table 2. Comparison of analytical result of CRM Soil-5 and Dolt-3 with certified concentrations using AAS Perkin Elmer A Analyst $800(n=3)$.

\begin{tabular}{ccccc}
\hline Heavy metals & CRM & $\begin{array}{c}\text { Certified values } \\
(\mu \mathrm{g} / \mathrm{g})\end{array}$ & $\begin{array}{c}\text { Measured values } \\
(\mu \mathrm{g} / \mathrm{g})\end{array}$ & $\begin{array}{c}\text { Recovery } \\
(\%)\end{array}$ \\
\hline $\mathrm{Cu}$ & Soil-5 & $77.1 \pm 4.7$ & $75.62 \pm 5.0$ & 99 \\
& DOLT-3 & $31.2 \pm 1.0$ & $29.8 \pm 2.7$ & 96 \\
$\mathrm{Zn}$ & Soil-5 & $368.0 \pm 8.20$ & $362.9 \pm 15.6$ & 100 \\
& DOLT-3 & $86.6 \pm 2.4$ & $83.8 \pm 3.5$ & 97 \\
$\mathrm{~Pb}$ & Soil-5 & $129.0 \pm 26.0$ & $124.8 \pm 22.0$ & 97 \\
& DOLT-3 & $0.32 \pm 0.05$ & $0.38 \pm 0.09$ & 109 \\
$\mathrm{Cd}$ & Soil-5 & $1.5 \pm 0.0$ & $1.56 \pm 0.03$ & 101 \\
& DOLT-3 & $19.4 \pm 0.6$ & $20.5 \pm 0.4$ & 105 \\
$\mathrm{Ni}$ & Soil-5 & $13 \pm 0.00$ & $12.85 \pm 1.02$ & 107 \\
& DOLT-3 & $2.72 \pm 0.35$ & $2.77 \pm 0.74$ & 101.8 \\
\hline
\end{tabular}




\section{1) Index of Geo accumulation (Igeo)}

The Igeo accumulation index is a quantitative measure of the degree of pollution in aquatic sediments [35]. Igeo, proposed by [36], calculate metal concentration in sediments by comparing current concentration with pre-industrial, undisturbed or crustal sediments levels, was used to quantitatively estimate the metal pollution status of sediments. Enrichment of metal concentration above baseline concentrations was calculated using (Equation (1)) the method proposed by [37], termed the geo accumulation index (Igeo). Igeo is mathematically expressed as:

$$
\operatorname{Igeo}=\log _{2}(\mathrm{Cn} / 1.5 \mathrm{Bn})
$$

where $\mathrm{Cn}$ is the measured concentration of the examined metal " $n$ " in the sediment and $\mathrm{Bn}$ is the geochemical background concentration of the metal " $\mathrm{n}$ ". The factor 1.5 was used to analyse natural fluctuations in the content of a given substance in the environment and to detect very small anthropogenic influences [38]. The factor 1.5 was introduced in the equation to minimise the effect of possible variations in the background values, which may be attributed to lithogenic variations in soils. Igeo assesses the metal pollution in terms of seven enrichment classes ( 0 to 6 ) ranging from background concentration to very heavily polluted, as shown in Table 4.

2) Enrichment Factor (EF)

Enrichment factor is a common approach to estimate how much the sediment is impacted (naturally and anthropogenically) with heavy metal [40], and is used to identify the precise origin(s) of the elements [41] [42]. Enrichment factor is computed relative to the abundance of species in source material to that found in the earth crust [43]. EF is generally defined as the observed metal to Fe ratio in a sample divided by the background metal/Fe ratio. EF is calculated using

Table 3. Background concentrations of sediment used in the calculation of pollution indices.

\begin{tabular}{cccccccc}
\hline Background concentrations & $\mathrm{Cu}$ & $\mathrm{Zn}$ & $\mathrm{Pb}$ & $\mathrm{Cd}$ & $\mathrm{Ni}$ & $\mathrm{Fe}$ & References \\
\hline $\begin{array}{c}\text { World average shale } \\
\begin{array}{c}\text { Lowest concentration } \\
\text { in the present study }\end{array}\end{array}$ & 95 & 95 & 20 & 0.30 & 68 & 4.70 & {$[34]$} \\
\hline
\end{tabular}

Table 4. Igeo classes in relation to sediment quality [39].

\begin{tabular}{ccc}
\hline Igeo & Igeo classes & Pollution intensity \\
\hline$<0$ & 0 & Unpolluted \\
$0-1$ & 1 & Unpolluted to moderately polluted \\
$1-2$ & 2 & Moderately polluted \\
$2-3$ & 3 & Moderately to strongly polluted \\
$3-4$ & 4 & Strongly polluted \\
$4-5$ & 5 & Strongly to very strongly polluted \\
$>5$ & 6 & Very strongly polluted \\
\hline
\end{tabular}


(Equation (2)) as follows;

$$
\mathrm{EF}=(\mathrm{Cn} / \mathrm{Fe}) \text { sample } /(\mathrm{Cn} / \mathrm{Fe}) \text { background }
$$

where: $\mathrm{Cn}$ is the concentration of element " $\mathrm{n}$ ".

To calculate the EF of a metal, the normalizer and the background levels of the metals should be determined. The geochemical normalization was obtained by using $\mathrm{Fe}$ as the reference element. Because $\mathrm{Fe}$ is one of the most abundant elements on Earth and usually poses no contamination concern, it is the frequent choice for normalization purposes. EF classes and sediment quality were shown in Table 5.

3) Pollution Load Index (PLI)

Pollution Load Index (PLI) is defined as an empirical index which provides a simple, comparative means for assessing the level of heavy metals pollution between different sites and at different times. It was employed by [45] to assess the extent of pollution by metals in estuarine sediments [46]. The PLI for a single site is the $\mathrm{nth}$ root of $\mathrm{n}$ number of multiplied contamination factor (CF) values as calculated using Equation (3).

$$
\text { PLI for a site }=(\mathrm{CF} 1 \times \mathrm{CF} 2 \times \cdots \times \mathrm{CFn}) 1 / \mathrm{n}
$$

where: $\mathrm{CF}=\mathrm{C}$ metal concentration/C background concentration of the same metal.

A PLI value of zero indicates perfection, a value of one that only baseline levels of pollutants are present and values above one would indicate progressive deterioration of the site and estuarine quality [45]. The PLI value of $>1$ indicates polluted, whereas PLI value $<1$ indicates no pollution [47] [48].

\subsection{Statistical Analyses}

All statistical analyses of data were carried out using SPSS statistical package programs version 17. Data were tested for the basic assumptions of normality and homogeneity of variance in exploratory data analysis in SPSS 17. ANOVA was calculated, post host comparison was made using Duncan's multiple range test at 0.05 confidence level. The strength and significance of the relationships between metal concentrations $\mathrm{Cu}, \mathrm{Zn}, \mathrm{Pb}, \mathrm{Cd}$ and $\mathrm{Ni}$ in the sediments were

Table 5. EF classes in relation to sediment quality [44].

\begin{tabular}{cc}
\hline EF Classes & Sediment quality \\
$<1$ & Indicates no enrichment \\
$<3$ & Presence of minor enrichment \\
$3-5$ & Moderate enrichment \\
$5-10$ & Moderately to severe enrichment \\
$10-25$ & Severe enrichment \\
$25-50$ & Very severe enrichment \\
$>50$ & Extremely severe enrichment
\end{tabular}


tested by the Pearson's correlation coefficients ( $r$ ).

\section{Results and Discussion}

\subsection{Results}

\subsubsection{Heavy Metals Concentrations in the Surface Sediments}

The means heavy metals concentrations in the surface sediments were presented in Table 6. The highest concentrations of $\mathrm{Cu}, \mathrm{Zn}$ and $\mathrm{Ni}$ were observed at sampling site 2 as $65.39 \pm 0.70,442.19 \pm 4.13$ and $29.25 \pm 0.08$ respectively and that of $\mathrm{Pb}$ and $\mathrm{Cd}$ were observed at sampling site 5 as $53.73 \pm 0.18$ and $1.65 \pm 0.11$ respectively. Statistical analysis showed that metal concentrations $\mathrm{Cu}, \mathrm{Zn}, \mathrm{Pb}, \mathrm{Cd}$ and $\mathrm{Ni}$ were significantly different $(\mathrm{p}<0.05)$ between the sampling sites. Iron was used as reference element for the normalization purposes in the calculation of EF.

\subsubsection{Particle Size Analysis of the Surface Sediments}

The result of particle size analysis was presented in Table 7. Four classes of grain size sediments were identified; sandy clay loam, silt clay, clay and sandy loam. The result revealed higher percentage of sand $(52.08 \%-72.66 \%)$ at sampling sites 1, 2, 5 and 6 and the sediments were classified as sandy clay loam. High percentage of clay particles $(75.81 \%)$ dominated surface sediment from sampling site 4 while sampling site 3 showed mixture of clay (47.74\%) and silt (40.09\%) sediments at these sites and were classified as clay and silty clay respectively.

Table 6. Mean heavy metal concentrations ( $\mu \mathrm{g} / \mathrm{gd} / \mathrm{w} \pm \mathrm{SE}$, except Fe in percentage \%) in the surface sediments.

\begin{tabular}{ccccccc}
\hline Sampling sites & $\mathrm{Cu}$ & $\mathrm{Zn}$ & $\mathrm{Pb}$ & $\mathrm{Cd}$ & $\mathrm{Ni}$ & $\mathrm{Fe}$ \\
\hline 1 & $34.79 \pm 0.19$ & $60.83 \pm 1.74$ & $27.78 \pm 1.41$ & $1.25 \pm 0.04$ & $13.11 \pm 0.16$ & $1.98 \pm 0.00$ \\
2 & $65.39 \pm 0.70$ & $442.19 \pm 4.13$ & $29.97 \pm 0.36$ & $1.24 \pm 0.08$ & $29.25 \pm 0.08$ & $2.78 \pm 0.04$ \\
3 & $35.48 \pm 0.64$ & $256.50 \pm 2.40$ & $34.22 \pm 0.23$ & $1.37 \pm 0.06$ & $26.42 \pm 0.24$ & $2.14 \pm 0.01$ \\
4 & $12.79 \pm 0.57$ & $75.38 \pm 1.63$ & $8.46 \pm 0.83$ & $0.60 \pm 0.05$ & $10.09 \pm 0.54$ & $1.89 \pm 0.00$ \\
5 & $37.64 \pm 0.95$ & $241.87 \pm 0.78$ & $53.73 \pm 0.18$ & $1.65 \pm 0.11$ & $21.18 \pm 0.48$ & $3.31 \pm 0.09$ \\
6 & $13.90 \pm 0.03$ & $117.38 \pm 0.99$ & $28.28 \pm 0.11$ & $1.40 \pm 0.14$ & $11.89 \pm 0.29$ & $3.67 \pm 0.02$
\end{tabular}

Table 7. Percentage grain size distribution and type of surface sediments.

\begin{tabular}{ccccc}
\hline Sampling sites & Clay (\%) & Silt (\%) & Sand (\%) & Sediment type \\
\hline 1 & 22.67 & 11.68 & 65.57 & sandy clay loam \\
2 & 24.9 & 22.88 & 52.08 & sandy clay loam \\
3 & 47.74 & 40.09 & 12.08 & silty clay \\
4 & 75.81 & 23.94 & 0.22 & clay \\
5 & 17.44 & 9.71 & 72.66 & sandy loam \\
6 & 22.73 & 19.73 & 57.41 & sandy clay loam \\
\hline
\end{tabular}




\subsubsection{Correlation between Particle Size Distribution and Total Metals}

The correlations coefficients based on the relationship between particle size distribution and total heavy metals $(\mathrm{Cu}, \mathrm{Zn}, \mathrm{Pb}, \mathrm{Cd}$ and $\mathrm{Ni}$ ) were presented in $\mathrm{Ta}$ ble 8 . The Pearson's correlation analysis shows negative correlations between clay particle with; TLCu $(\mathrm{r}=-0.564)$, TLCd $(\mathrm{r}=-0.528)$ at $\mathrm{p}<0.05$ and TLPb $(\mathrm{r}$ $=-0.792 ; \mathrm{p}<0.01)$. Sand particle shows positive correlations with TLPb $(\mathrm{r}=$ $0.671 ; \mathrm{p}<0.01)$ and TLCd $(0.479 ; \mathrm{p}<0.05)$. Negative correlations were observed between fine grain particle with TLPb $(\mathrm{r}=-0.673$; $\mathrm{p}<0.01)$ and TLCd $(\mathrm{r}=$ $-0.489 ; \mathrm{p}<0.05)$ while non-significant correlations were observed between silt particle with all the six heavy metals.

\subsubsection{Correlation between Heavy Metals Concentrations}

Pearson's correlation analysis was used to test the relationship between the heavy metals analysed in the present study. The correlation matrix showed that $\mathrm{Cu}, \mathrm{Zn}, \mathrm{Pb}, \mathrm{Cd}$ and $\mathrm{Ni}$ were correlated with each other, showing a strong positive associations $(\mathrm{r}=0.753-0.805 ; \mathrm{p}<0.01)$ and a positive correlations of lesser confidence $(0.519-0.588 ; \mathrm{p}<0.05)$ among the heavy metals.

Non-significant correlations ( $\mathrm{p}>0.05$ ) were observed between $\mathrm{Cu}$ and $\mathrm{Cd}(\mathrm{r}=$ $0.312), \mathrm{Ni}$ also shows a non-significant correlation with $\mathrm{Pb}(\mathrm{r}=0.414)$ and $\mathrm{Cd}(\mathrm{r}$ $=0.074)$ at $\mathrm{p}>0.05$ (Table 9).

\subsubsection{Index of Geo Accumulation (Igeo)}

The means Igeo based on world average shale and lowest concentration in the present study were presented in Table 10. The Igeo index based on world average shale [34], showed that $100 \%$ of $\mathrm{Cu}, \mathrm{Zn}, \mathrm{Pb}, \mathrm{Ni}$ and $96 \%$ of Cd falls into class 1 (unpolluted), and $4 \%$ of Cd falls into class 2 (moderately polluted).

The Igeo index calculated based on the lowest concentration showed $100 \%$ of

Table 8. Correlations coefficients between particle size distribution and total heavy metals.

\begin{tabular}{cccccc}
\hline Particle size/Total heavy metals & TLCu & TLZn & TLPb & TLCd & TLNi \\
\hline Clay & $-0.564^{*}$ & -0.236 & $-0.792^{* *}$ & $-0.528^{*}$ & -0.277 \\
Silt & -0.048 & 0.38 & -0.202 & -0.247 & 0.392 \\
Sand & 0.441 & 0.025 & $0.671^{* *}$ & $0.479^{\star}$ & 0.057 \\
Finegrain & -0.445 & -0.04 & $-0.673^{* *}$ & $-0.489^{*}$ & -0.067 \\
\hline
\end{tabular}

${ }^{\star}$ Correlation is significant at the 0.05 level (2 tailed). ${ }^{* *}$ Correlation is significant at the 0.01 level (2-tailed).

Table 9. Relationships between heavy metals concentrations in the surface sediments.

\begin{tabular}{cccccc}
\hline Metals & $\mathrm{Cu}$ & $\mathrm{Zn}$ & $\mathrm{Pb}$ & $\mathrm{Cd}$ & $\mathrm{Ni}$ \\
\hline $\mathrm{Zn}$ & $0.576^{*}$ & 1 & & & \\
$\mathrm{~Pb}$ & $0.558^{*}$ & $0.588^{*}$ & 1 & & \\
$\mathrm{Cd}$ & 0.312 & $0.519^{*}$ & $0.753^{* *}$ & 1 & 1 \\
$\mathrm{Ni}$ & $0.805^{* *}$ & $0.799^{* *}$ & 0.414 & 0.074 & \\
${ }^{* *}$ Correlation is significant at the 0.01 level (2-tailed). ${ }^{*}$ Correlation is significant at the 0.05 level (2-tailed).
\end{tabular}


Table 10. Means Igeo Index and their classes indicated by superscript numbers.

\begin{tabular}{|c|c|c|c|c|c|c|}
\hline \multirow{2}{*}{ Sampling sites } & \multirow{2}{*}{$\begin{array}{l}\text { Background } \\
\text { Concentrations }\end{array}$} & \multicolumn{5}{|c|}{ Igeo values and classes } \\
\hline & & $\mathrm{Cu}$ & $\mathrm{Zn}$ & $\mathrm{Pb}$ & $\mathrm{Cd}$ & $\mathrm{Ni}$ \\
\hline 1 & World average shale & $0.13^{\mathrm{a}}$ & $0.14^{\mathrm{a}}$ & $0.27^{\mathrm{a}}$ & $0.73^{\mathrm{a}}$ & $0.05^{\mathrm{a}}$ \\
\hline 2 & & $0.32^{\mathrm{a}}$ & $0.85^{\mathrm{a}}$ & $0.29^{\mathrm{a}}$ & $0.86^{\mathrm{a}}$ & $0.06^{\mathrm{a}}$ \\
\hline 3 & & $0.19^{\mathrm{a}}$ & $0.51^{\mathrm{a}}$ & $0.41^{\mathrm{a}}$ & $0.76^{\mathrm{a}}$ & $0.09^{\mathrm{a}}$ \\
\hline 4 & & $0.06^{\mathrm{a}}$ & $0.14^{\mathrm{a}}$ & $0.10^{\mathrm{a}}$ & $0.39^{\mathrm{a}}$ & $0.10^{\mathrm{a}}$ \\
\hline 5 & & $0.17^{\mathrm{a}}$ & $0.52^{\mathrm{a}}$ & $0.61^{\mathrm{a}}$ & $1.90^{\mathrm{b}}$ & $0.07^{\mathrm{a}}$ \\
\hline 6 & & $0.07^{\mathrm{a}}$ & $0.26^{\mathrm{a}}$ & $0.33^{\mathrm{a}}$ & $0.84^{\mathrm{a}}$ & $0.04^{\mathrm{a}}$ \\
\hline 1 & Present study & $0.59^{\mathrm{a}}$ & $0.20^{\mathrm{a}}$ & $2.07^{\mathrm{c}}$ & $0.38^{\mathrm{a}}$ & $0.27^{\mathrm{a}}$ \\
\hline 2 & & $1.48^{\mathrm{b}}$ & $1.21^{\mathrm{b}}$ & $2.22^{\mathrm{c}}$ & $0.45^{\mathrm{a}}$ & $0.62^{\mathrm{a}}$ \\
\hline 3 & & $0.87^{\mathrm{a}}$ & $0.73^{\mathrm{a}}$ & $3.15^{\mathrm{d}}$ & $0.39^{\mathrm{a}}$ & $0.55^{\mathrm{a}}$ \\
\hline 4 & & $0.28^{\mathrm{a}}$ & $0.20^{\mathrm{a}}$ & $0.79^{\mathrm{a}}$ & $0.20^{\mathrm{a}}$ & $0.20^{\mathrm{a}}$ \\
\hline 5 & & $0.78^{\mathrm{a}}$ & $0.74^{\mathrm{a}}$ & $4.75^{\mathrm{e}}$ & $0.46^{\mathrm{a}}$ & $0.40^{\mathrm{a}}$ \\
\hline 6 & & $0.32^{\mathrm{a}}$ & $0.37^{\mathrm{a}}$ & $2.56^{\mathrm{c}}$ & $0.43^{\mathrm{a}}$ & $0.24^{\mathrm{a}}$ \\
\hline
\end{tabular}

Igeo: ${ }^{a}$ unpolluted to moderately polluted; ${ }^{b}$ moderately polluted; ${ }^{c}$ strongly to moderately polluted; ${ }^{\mathrm{d}}$ strongly



$\mathrm{Cd}, \mathrm{Ni}$ and $96 \%$ of $\mathrm{Cu}, \mathrm{Zn}$ falls into class 1 (unpolluted). $\mathrm{Cu}$ and $\mathrm{Zn}$ were found to be moderately polluted (class 2 ) at sampling g site 2 . The Igeo index of $\mathrm{Pb}$ shows that $50 \%$ of $\mathrm{Pb}$ falls into class 3 (moderately to strongly polluted) and $16.66 \%$ of $\mathrm{Pb}$ fall into; class 5 (strongly to very strongly polluted), class 4 (strongly polluted) and class 1 (unpolluted) at sampling sites 5, 3 and 4 respectively.

\subsubsection{Enrichment Factor (EF)}

An enrichment factor was used to differentiate metals from anthropogenic (non-crustal) and geogenic (crustal) sources and to further evaluate the magnitude of contamination in the environment (Feng et al., 2004). Table 11 shows mean $\mathrm{EF}$ values of heavy metals. The mean $\mathrm{EF}$ of $\mathrm{Cu}$ mostly shows minor enrichment $(\mathrm{EF}<3)$, and moderately severe enrichment $(\mathrm{EF}=5.02)$ at sampling site 2. The EF value for $\mathrm{Cu}$ at sampling sites 4 and 6 showed no enrichment (EF $<1)$ in respect to world average shale, while minor enrichment $(E F=1.40)$ and no enrichment $(\mathrm{EF}<1)$ were observed at sampling sites 4 and 6 respectively for the $\mathrm{EF}$ of $\mathrm{Cu}$ calculated from the lowest concentration. Ni showed no enrichment $(\mathrm{EF}<1)$ at all the sampling sites in respect to world average shale except at sampling site 3 were minor enrichment $(\mathrm{EF}<3$ was observed in respect to the lowest concentration. Minor enrichment $(\mathrm{EF}<3)$ of about $67 \%$ was observed for $\mathrm{Ni}$ from the lowest concentration in the present study. The EF values for $\mathrm{Zn}$ showed no enrichment $(\mathrm{EF}<1)$ to moderately severe enrichment $(\mathrm{EF}=5-10)$. $\mathrm{EF}$ values of $\mathrm{Pb}$ showed minor enrichment $(\mathrm{EF}<3)$ to severe enrichment $(\mathrm{EF}=$ 10 - 25). The mean EF values of Cd calculated based on lowest concentration showed minor enrichment $(\mathrm{EF}<3)$ at all the sampling sites. The highest $\mathrm{EF}$ values 
Table 11. Means EF of heavy metals and their classes indicated by superscript letters.

\begin{tabular}{ccccccc}
\hline \multirow{2}{*}{ Sampling sites } & \multirow{2}{*}{$\begin{array}{c}\text { Background } \\
\text { Concentrations }\end{array}$} & \multicolumn{5}{c}{ Enrichment Factor (EF) } \\
\cline { 3 - 6 } & World average shale & $1.50^{\mathrm{b}}$ & $1.68^{\mathrm{b}}$ & $3.16^{\mathrm{c}}$ & $9.23^{\mathrm{d}}$ & $0.54^{\mathrm{a}}$ \\
\hline 1 & $2.68^{\mathrm{b}}$ & $7.19^{\mathrm{d}}$ & $2.41^{\mathrm{b}}$ & $7.74^{\mathrm{d}}$ & $0.87^{\mathrm{a}}$ \\
\hline 3 & $2.06^{\mathrm{b}}$ & $5.62^{\mathrm{d}}$ & $4.46^{\mathrm{c}}$ & $8.91^{\mathrm{d}}$ & $1.00^{\mathrm{b}}$ \\
4 & $0.75^{\mathrm{a}}$ & $1.74^{\mathrm{b}}$ & $1.25^{\mathrm{b}}$ & $5.15^{\mathrm{d}}$ & $0.42^{\mathrm{a}}$ \\
5 & $1.20^{\mathrm{b}}$ & $3.70^{\mathrm{c}}$ & $4.33^{\mathrm{c}}$ & $6.79^{\mathrm{d}}$ & $0.47^{\mathrm{a}}$ \\
6 & & $0.44^{\mathrm{a}}$ & $1.64^{\mathrm{b}}$ & $2.10^{\mathrm{b}}$ & $5.72^{\mathrm{d}}$ & $0.26^{\mathrm{a}}$ \\
1 & & $2.81^{\mathrm{b}}$ & $0.96^{\mathrm{a}}$ & $9.89^{\mathrm{d}}$ & $1.79^{\mathrm{b}}$ & $1.29^{\mathrm{b}}$ \\
2 & & $5.02^{\mathrm{d}}$ & $4.12^{\mathrm{c}}$ & $7.55^{\mathrm{d}}$ & $1.50^{\mathrm{b}}$ & $2.09^{\mathrm{b}}$ \\
3 & & $3.85^{\mathrm{c}}$ & $3.23^{\mathrm{c}}$ & $13.96^{\mathrm{e}}$ & $1.72^{\mathrm{b}}$ & $2.41^{\mathrm{b}}$ \\
\hline 4 & & $1.40^{\mathrm{b}}$ & $1.00^{\mathrm{b}}$ & $3.93^{\mathrm{c}}$ & $1.00^{\mathrm{b}}$ & $1.00^{\mathrm{b}}$ \\
\hline 5 & & $2.24^{\mathrm{b}}$ & $2.12^{\mathrm{b}}$ & $13.55^{\mathrm{e}}$ & $1.31^{\mathrm{b}}$ & $1.13^{\mathrm{b}}$ \\
\hline 6 & & $0.82^{\mathrm{a}}$ & $0.94^{\mathrm{a}}$ & $6.59^{\mathrm{d}}$ & $1.11^{\mathrm{b}}$ & $0.61^{\mathrm{a}}$ \\
\hline
\end{tabular}

EF: ${ }^{\mathrm{a}}$ no enrichment; ${ }^{\mathrm{b}}$ minor enrichment; ${ }^{\mathrm{c}}$ moderate enrichment; ${ }^{\mathrm{d}}$ moderately severe enrichment; ${ }^{\mathrm{e}}$ severe enrichment; ${ }^{\mathrm{f}}$ very severe enrichment.

Table 12. Values of pollution load index in the surface sediments.

\begin{tabular}{ccc}
\hline Sampling sites & World average shale & Lowest concentration in the present study \\
\hline 1 & 0.89 & 2.45 \\
2 & 1.78 & 4.92 \\
3 & 1.45 & 4.01 \\
4 & 0.49 & 1.35 \\
5 & 1.58 & 4.35 \\
6 & 0.85 & 2.34 \\
\hline
\end{tabular}

PLI: PLI value of $>1$ indicates polluted, whereas PLI value $<1$ indicates no pollution.

for $\mathrm{Cu}, \mathrm{Zn}, \mathrm{Pb}, \mathrm{Cd}$ and $\mathrm{Ni}$ were observed at sampling sites 2, 2, 3, 1 and 3 respectively for the world average shale and lowest concentration of the present study.

\subsubsection{Pollution Load Index (PLI)}

The calculated PLI values ranged from $0.45-1.78$ at sampling sites 3 and 2 respectively for world average shale and $1.35-4.92$ at sampling sites 4 and 2 respectively in respect to lowest concentration in the present study (Table 12). The order of PLI from highest to lowest values was; $2>5>3>1>6>4$ for world average shale and lowest concentration in the present study.

\subsection{Discussion}

Grain size is an important factor to evaluate heavy metals concentration in the sediment [49]. The particle size analysis of the surface sediments showed that 
sand and clay content appeared to be the principal sediment types at sampling sites 1, 2, 5 and 6 while sampling sites 3 and 4 contained higher mixture of clay and silt content with low sand substrates. Many studies have shown that mangrove sediments act as a trap for chemical contaminants because such sediments contain high percentage of silt and clay that cause an increase in the metals adsorption [50] [51] [52] [53] and indicated that heavy metal concentrations decrease with the increase of particle size, and the highest content levels occur in the finest fractions [44] [54] [55] [56]. High metals concentrations were observed at sampling sites with high content of sand and clay particles. Coarser particles may as well show higher concentration of heavy metals than finer ones in some instances, and the presence of coarse particles is possibly the reason for higher metal content [57] [58].

Pearson's correlation analysis was applied to test the relationships among heavy metals in the surface sediments of the west coast of Peninsular Malaysia. The results of correlation matrix showed that $\mathrm{Cu}, \mathrm{Zn}, \mathrm{Pb}, \mathrm{Cd}$ and Ni were correlated significantly with each other except for few cases $(\mathrm{Cu}$ and $\mathrm{Cd}$; $\mathrm{Ni}$ and $\mathrm{Pb}$; and $\mathrm{Ni}$ and $\mathrm{Cd}$ ) in the surface sediments. This finding is in good agreement with the studies conducted by [59] who reported significant correlation $(\mathrm{p}<0.01)$ between $\mathrm{Cd}$ and $\mathrm{Pb}$ from marine sediments of Jinzhou Bay, China and that of [60] between $\mathrm{Cu}$ and $\mathrm{Zn}, \mathrm{Cu}$ and $\mathrm{Pb}$, and $\mathrm{Zn}$ and $\mathrm{Pb}$ from urban soils in Nanjing, China.

The strong positive correlation coefficients between $\mathrm{Cu}$ and $\mathrm{Ni}(\mathrm{r}=0.805), \mathrm{Zn}$ and $\mathrm{Ni}(\mathrm{r}=0.799)$ and $\mathrm{Pb}$ and $\mathrm{Cd}(\mathrm{r}=0.753)$ was significantly observed suggesting some relationship between the metals and indicating their similar source of origin [59] [61] [62]. The low correlation coefficient of $\mathrm{Cu}$ and $\mathrm{Cd}, \mathrm{Pb}$ and $\mathrm{Ni}$, and $\mathrm{Cd}$ and $\mathrm{Ni}$ in the sediments suggests these metals may originate from different sources or that they might have different sediment deposition characteristics [63].

The Igeo indexing approach was used to quantify the degree of anthropogenic contamination, and to compare the different metals in aquatic sediments [36] [37] [64], by comparing current concentrations with pre-industrial levels [36]. The result of geo accumulation index (Igeo) based on world average shale shows that all the sampling sites were considered as unpolluted to moderately polluted with $\mathrm{Cu}, \mathrm{Zn}, \mathrm{Pb}$, and $\mathrm{Ni}$. Cadmium was considered moderately polluted at sampling site 5 while the remaining 5 sampling sites were considered as unpolluted with Cd.

The calculated Igeo values based on the lowest concentration in the present study shows that all the sampling sites were unpolluted with $\mathrm{Cu}, \mathrm{Zn}, \mathrm{Cd}$ and $\mathrm{Ni}$ except sampling site 2 which was moderately polluted with $\mathrm{Cu}$ and $\mathrm{Zn}$. The pollution intensity of $\mathrm{Pb}$ shows that most of the sampling sites were moderately to strongly polluted with $\mathrm{Pb}$ while sampling site 5 was considered strongly to very strongly polluted with $\mathrm{Pb}$, sampling site 4 was the only site considered unpolluted with lead. Among the metals analysed, $\mathrm{Pb}$ shows the highest Igeo values at 
the entire sampling site which might suggest $\mathrm{Pb}$ in the sediment was most significantly impacted by anthropogenic sources. The Igeo values for $\mathrm{Pb}$ might be associated with fuel used in jetties and industries. This is in agreement with [65] that, the presence of $\mathrm{Pb}$ in sediment cores might have been originated from the anthropogenic fly-ashes derived from the combustion of fossil fuels in industries, boat, ship and other vehicles. According to the calculated Igeo values, five sampling sites were strongly polluted with $\mathrm{Pb}$, sampling site 2 was moderately polluted with $\mathrm{Cu}$ and $\mathrm{Zn}$ while sampling site 5 was moderately polluted with $\mathrm{Cd}$.

In general, the index of geo accumulation (Igeo) indicates that the surface sediments collected from the sampling sites were unpolluted to moderately polluted (Class 1 ) to strongly to very strongly polluted (Class 5 ). The Igeo values for $\mathrm{Cu}, \mathrm{Zn}, \mathrm{Pb}$ and $\mathrm{Ni}$ calculated from the lowest concentration found in the present study were higher than those calculated from the world average shale which may suggest anthropogenic input of these metals in the sediment.

In order to distinguish anthropogenic pollutants from natural content in the sediment, enrichment factors (EF) were calculated. The enrichment factors in the surface sediments varied between no enrichment to severe enrichment depending on the sampling sites and heavy metal. The EF values for $\mathrm{Cu}$ showed no enrichment to moderately severe enrichment and the $\mathrm{EF}$ for $\mathrm{Zn}$ and $\mathrm{Pb}$ show no enrichment to severe enrichment. The highest enrichment of $\mathrm{Cu}$ and $\mathrm{Zn}$ were mostly found at sampling site 2 , and that of $\mathrm{Pb}$ was found at sampling site 3 as 13.96 which might suggest high anthropogenic activities as a result of domestic and industrial input at these sampling sites. EFs greater than 10 are considered to be non-crustal source [66] [67].

The EF values of $\mathrm{Cd}$ showed minor enrichment to moderately severe enrichment while the EF calculated from the lowest concentration found in the present study showed minor enrichment of $\mathrm{Cd}$ with highest mean value at sampling site 1. Nickel shows lowest EF values among the metals studied, the EF values indicated no enrichment to minor enrichment. The highest mean $\mathrm{EF}$ value of $\mathrm{Ni}$ was found at sampling site 3, which was associated with influx of domestic sewage and industrial activities in the area. All the EF values calculated for $\mathrm{Cu}, \mathrm{Pb}$ and $\mathrm{Ni}$ using the lowest concentrations found in the present study were higher than the EF values calculated from the world average shale background which indicates these metals were enriched at the sampling sites. The EF values of $\mathrm{Zn}$ and $\mathrm{Cd}$ were all higher from the world average shale when compared with EF values from the lowest concentrations in the present study. The concentration of crustal elements may vary by location [68] and could result in overestimation or underestimation of the EF [69].

The PLI values calculated based on world average shale and the lowest concentration found in the present study indicates strong signs of pollution deterioration by the metals studied at all the sampling sites. The PLI value with respect to world average shale indicates that the metals were within the baseline level at sampling sites 1, 6, and 4 which implied no appreciable input from anthropo- 
genic sources. The lowest concentration found in the present study shows higher PLI values than the world average shale background concentrations, clearly demonstrating anthropogenic contribution of metals. The highest degree of pollution based on PLI value was observed at sampling site 2 followed by sampling site 5 and lowest at sampling site 4 . The order of sampling sites from highest to lowest PLI values was; $2>5>3>1>6>4$.

\section{Conclusion}

The results obtained from this study indicate heavy metals contamination in the study area, particularly $\mathrm{Pb}$. Heavy metals concentrations in the sediments varied significantly among the sampling sites. Higher concentrations of heavy metals were generally observed at sampling sites close to anthropogenic inputs from domestic, industrial, shipping or other sources of pollution. The contamination of $\mathrm{Pb}$ in the study area could be associated with fuel and oil lubricants used in jetties and industries which might have been originated from paint flakes from boats, sewage sludge and anthropogenic fly-ashes derived from the combustion of fossil fuels in industries, boat, ship and other vehicles. Hence, management practices, monitoring and Government policy should be employed for regulating contamination of this coastal environment by controlling effluent discharge from anthropogenic sources which is required to protect the marine ecosystem from deterioration. Further study on the physico-chemical parameters of water and sediments that could affect bioavailability, accumulation and toxicity of these metals in fishes, shell fishes and other aquatic resources should further be investigated.

\section{Conflicts of Interest}

The authors declare no conflicts of interest regarding the publication of this paper.

\section{References}

[1] Bermejo, J.C.S., Beltrán, R. and Ariza, J.G. (2003) Spatial Variations of Heavy Metals Contamination in Sediments from Odiel River (Southwest Spain). Environment International, 29, 69-77. https://doi.org/10.1016/S0160-4120(02)00147-2

[2] Shomar, B.H., Müller, G. and Yahya, A. (2005) Seasonal Variations of Chemical Composition of Water and Bottom Sediments in the Wetland of Wadi Gaza, Gaza Strip. Wetlands Ecology and Management, 13, 419-431.

https://doi.org/10.1007/s11273-004-0412-3

[3] Chapman, P.M., Wang, F. and Caeiro, S.S. (2013) Assessing and Managing Sediment Contamination in Transitional Waters. Environment International, 55, 71-91. https://doi.org/10.1016/j.envint.2013.02.009

[4] Silva, A.F., Lima, G.R., Alves, J.C., Santos, S.H., Garcia, C.A., Alves, J.P.H., Araujo, R.G. and Passos, E.A. (2012) Evaluation of Trace Metal Levels in Surface Sediments of the Sergipe River Hydrographic Basin, Northeast Brazil. Journal of the Brazilian Chemical Society, 23, 1669-1679. https://doi.org/10.1590/S0103-50532012005000028 
[5] Barbieri, M. (2016) The Importance of Enrichment Factor (EF) and Geoaccumulation Index (Igeo) to Evaluate the Soil Contamination. Journal of Geology and Geophysics, 5, 1-4. https://doi.org/10.4172/2381-8719.1000237

[6] MacFarlane, G. and Burchett, M. (2000) Cellular Distribution of Copper, Lead and Zinc in the Grey Mangrove, Avicennia marina (Forsk.). Vierh. Aquatic Botany, 68, 45-59. https://doi.org/10.1016/S0304-3770(00)00105-4

[7] United Nations Environmental Programme UNEP (2006) Marine and Coastal Ecosystems and Human Well-Being: A Synthesis Report Based on the Findings of the Millennium Ecosystem Assessment. Environmental Programme, Nairobi. http://www.unep.org

[8] Barbier, E.B., Hacker, S.D., Kennedy, C., Koch, E.W., Stier, A.C. and Silliman, B.R. (2011) The Value of Estuarine and Coastal Ecosystem Services. Ecological Monographs, 81, 169-193. https://doi.org/10.1890/10-1510.1

[9] Lotze, H.K., Lenihan, H.S., Bourque, B.J., Bradbury, R.H., Cooke, R.G., Kay, M.C., Kidwell, M., Kirby, M.X., Parterson, C.H. and Jackson, J.B. (2006) Depletion, Degradation, and Recovery Potential of Estuaries and Coastal Seas. Science, 312, 1806-1809. https://doi.org/10.1126/science.1128035

[10] Mora, C., Aburto-Oropeza, O., Bocos, A.A., Ayotte, P.M., Banks, S., Bauman, A.G., Brooks, A., et al. (2011) Global Human Footprint on the Linkage between Biodiversity and Ecosystem Functioning in Reef Fishes. PLoS Biology, 9, e1000606.

[11] Perry, R.I., Ommer, R.E., Barange, M., Jentoft, S., Neis, B. and Sumaila, U.R. (2011) Marine Social-Ecological Responses to Environmental Change and the Impacts of Globalization. Fish and Fisheries, 12, 427-450. https://doi.org/10.1111/j.1467-2979.2010.00402.x

[12] Sany, S.B.T., Salleh, A., Rezayi, M., Saadati, N., Narimany, L. and Tehrani, G.M. (2013) Distribution and Contamination of Heavy Metal in the Coastal Sediments of Port Klang, Selangor, Malaysia. Water, Air, \& Soil Pollution, 224, 1476. https://doi.org/10.1007/s11270-013-1476-6

[13] He, Q., Bertness, M.D., Bruno, J.F., Li, B., Chen, G., Coverdale, T.C., Altieri, A.H., Bai, J., Sun, T., Pennings, S.C., Liu, J., Ehrlich, P.R. and Cui, B. (2014) Economic Development and Coastal Ecosystem Change in China. Scientific Reports, 4, Article No. 5995. https://doi.org/10.1038/srep05995

[14] Hagan, G.B., Ofosu, F.G., Hayford, E.K., Osae, E.K. and Oduro-Afriyie, K. (2011) Heavy Metal Contamination and Physico-Chemical Assessment of the Densu River Basin in Ghana. Research Journal of Environmental and Earth Sciences, 3, 385-392.

[15] Lim, W.Y., Aris, A.Z. and Zakaria, M.P. (2012) Spatial Variability of Metals in Surface Water and Sediment in the Langat River and Geochemical Factors That Influence Their Water-Sediment Interactions. The Scientific World Journal, 2012, Article ID: 652150. https://doi.org/10.1100/2012/652150

[16] Praveena, S.M., Ahmed, A., Radojevic, M., Abdullah, M.H. and Aris, A.Z. (2008) Heavy Metals in Mangrove Surface Sediment of Mengkabong Lagoon, Sabah: Multivariate and Geo-Accumulation Index Approaches. International Journal of Environmental Research, 2, 139-148.

[17] Wang, W.X. (2002) Interactions of Trace Metals and Different Marine Food Chains. Marine Ecology Progress Series, 243, 295-309. https://doi.org/10.3354/meps243295

[18] Arellano, J., Ortiz, J., Da Silva, D.C., de Canales, M.L.G., Sarasquete, C. and Blasco, J. (1999) Levels of Copper, Zinc, Manganese and Iron in Two Fish Species from Salt Marshes of Cadiz Bay (Southwest Iberian Peninsula). Boletin del Instituto Espanol de Oceanografia, 15, 485-488. 
[19] Cohen, T., Que Hee, S.S. and Ambrose, R.F. (2001) Trace Metals in Fish and Invertebrates of Three California Coastal Wetlands. Marine Pollution Bulletin, 42, 224-232. https://doi.org/10.1016/S0025-326X(00)00146-6

[20] Ruilian, Y.U., Xing, Y., Yuanhui, Z., Gongren, H.U. and Xianglin, T.U. (2008) Heavy Metal Pollution in Intertidal Sediments from Quanzhou Bay, China. Journal of Environmental Sciences, 20, 664-669. https://doi.org/10.1016/S1001-0742(08)62110-5

[21] Chen, H.Z., Wang, J.G., Chen, J.M., Lin, H. and Lin, C. (2016) Assessment of Heavy Metal Contamination in the Surface Sediments: A Re-Examination into the Offshore Environment in China. Marine Pollution Bulletin, 113, 132-140. https://doi.org/10.1016/j.marpolbul.2016.08.079

[22] Nour, H.E., El-Sorogy, A.S., AbdEl-Wahab, M., Nouh, E., Mohamaden, M. and Al-Kahtany, K. (2019) Contamination and Ecological Risk Assessment of Heavy Metals Pollution from the Shalateen Coastal Sediments, Red Sea, Egypt. Marine Pollution Bulletin, 144, 167-172. https://doi.org/10.1016/j.marpolbul.2019.04.056

[23] Hossen, M.F., Hamdan, S., Rahman, M.R., Hossen, M.F., Hamdan, S. and Rahman, M.R. (2015) Review on the Risk Assessment of Heavy Metals in Malaysian Clams. The Scientific World Journal, 2015, Article ID: 905497. https://doi.org/10.1155/2015/905497

[24] Christophoridis, C., Dedepsidis, D. and Fytianos, K. (2009) Occurrence and Distribution of Selected Heavy Metals in the Surface Sediments of Thermaikos Gulf, N. Greece. Assessment Using Pollution Indicators. Journal of Hazardous Materials, 168, 1082-1091. https://doi.org/10.1016/j.jhazmat.2009.02.154

[25] Oluwagbemiga, A.P., Olatayo, A.A. and Funso, A.I. (2019) Coastal Marine Sediment Heavy Metals Contamination of a Transgressive Mud Beach, Ondo State, Southwest, Nigeria. Journal of Marine Science Research and Development, 9, 2.

[26] Kemaman, S., Yunus, K. and Chuan, O.M. (2009) Geochemical Proxy of Some Chemical Elements in Sediments of Kemaman River Estuary, Terengganu, Malaysia. Sains Malaysiana, 38, 631-636.

[27] Abubakar, U.S., Zulkifli, S.Z. and Ismail, A. (2018) Heavy Metals Bioavailability and Pollution Indices Evaluation in the Mangrove Surface Sediment of Sungai Puloh, Malaysia. Environmental Earth Sciences, 77, 225. https://doi.org/10.1007/s12665-018-7399-1

[28] Looi, L.J., Aris, A.Z., Yusoff, F.M., Isa, N.M. and Haris, H. (2019) Application of Enrichment Factor, Geoaccumulation Index, and Ecological Risk Index in Assessing the Elemental Pollution Status of Surface Sediments. Environmental Geochemistry and Health, 41, 27-42. https://doi.org/10.1007/s10653-018-0149-1

[29] Ismail, A. (1993) Heavy Metal Concentrations in Sediments off Bintulu, Malaysia. Marine Pollution Bulletin, 26, 706-707.

https://doi.org/10.1016/0025-326X(93)90556-Y

[30] Zulkifli, S.Z., Ismail, A., Mohamat-Yusuff, F., Arai, T. and Miyazaki, N. (2010) Johor Strait as a Hotspot for Trace Elements Contamination in Peninsular Malaysia. Bulletin of Environmental Contamination and Toxicology, 84, 568-573. https://doi.org/10.1007/s00128-010-9998-8

[31] Long, E.R., Field, L.J. and MacDonald, D.D. (1998) Predicting Toxicity in Marine Sediments with Numerical Sediment Quality Guidelines. Environmental Toxicology and Chemistry: An International Journal, 17, 714-727. https://doi.org/10.1002/etc.5620170428

[32] Gee, G.W., Bauder, J.W. and Klute, A. (1986) Particle-Size Analysis, Methods of Soil Analysis, Part 1. Physical and Mineralogical Methods, Soil since Society of America. 
WIS Inc., Madison.

[33] Skaggs, T.H., Arya, L.M., Shouse, P.J. and Mohanty, B.P. (2001) Estimating Particle-Size Distribution from Limited Soil Texture Data. Soil Science Society of America Journal, 65, 1038-1044. https://doi.org/10.2136/sssaj2001.6541038x

[34] Turekian, K.K. and Wedepohl, K.H. (1961) Distribution of the Elements in Some Major Units of the Earth's Crust. Geological Society of America Bulletin, 72, 175-192. https://doi.org/10.1130/0016-7606(1961)72[175:DOTEIS]2.0.CO;2

[35] Singh, K.P., Mohan, D., Singh, V.K. and Malik, A. (2005) Studies on Distribution and Fractionation of Heavy Metals in Gomti River Sediments-A Tributary of the Ganges, India. Journal of Hydrology, 312, 14-27.

https://doi.org/10.1016/j.jhydrol.2005.01.021

[36] Müller, G. (1979) Schwermetalle in den Sedimenten des Rheins-Veränderungenseit seit 1971.

[37] Müller, G. (1969) Index of Geoaccumulation in Sediments of the Rhine River. Geojournal, 2, 108-118.

[38] Yaqin, J.I., Yinchang, F., Jianhui, W.U., Tan, Z.H.U., Zhipeng, B.A.I. and Chiqing, D. (2008) Using Geoaccumulation Index to Study Source Profiles of Soil Dust in China. Journal of Environmental Sciences, 20, 571-578. https://doi.org/10.1016/S1001-0742(08)62096-3

[39] Müller, G. (1981) Die Schwermetallbelastung der sedimente des Neckars und seiner Nebenflusse: eineBestandsaufnahme. Chemical Zeitung, 105, 157-164.

[40] Huu Hieu, H.O., Swennen, R. and Van Damme, A. (2010) Distribution and Contamination Status of Heavy Metals in Estuarine Sediments near Cua ONg Harbor, Ha Long Bay, Vietnam. Geologicabelgica, 13, 37-47.

[41] Cukrov, N., Frančišković-Bilinski, S., Hlača, B. and Barišić, D. (2011) A Recent History of Metal Accumulation in the Sediments of Rijeka Harbor, Adriatic Sea, Croatia. Marine Pollution Bulletin, 62, 154-167. https://doi.org/10.1016/j.marpolbul.2010.08.020

[42] Frančišković-Bilinski, S. (2008) Detection of Coal Combustion Products in Stream Sediments by Chemical Analysis and Magnetic-Susceptibility Measurements. Mineralogical Magazine, 72, 43-48. https://doi.org/10.1180/minmag.2008.072.1.43

[43] Sinex, S.A. and Helz, G.R. (1981) Regional Geochemistry of Trace Elements in Chesapeake Bay Sediments. Environmental Geology, 3, 315-323.

https://doi.org/10.1007/BF02473521

[44] Birch, G.F. and Scollen, A. (2003) Heavy Metals in Road Dust, Gully Pots and Parkland Soils in a Highly Urbanised Sub-Catchment of Port Jackson, Australia. Soil Research, 41, 1329-1342. https://doi.org/10.1071/SR02147

[45] Tomlinson, D.L., Wilson, J.G., Harris, C.R. and Jeffrey, D.W. (1980) Problems in the Assessment of Heavy-Metal Levels in Estuaries and the Formation of a Pollution Index. Helgoländermeeresuntersuchungen, 33, 566-575.

https://doi.org/10.1007/BF02414780

[46] Satyanarayana, D., Panigrahy, P.K. and Sahu, S.D. (1994) Metal Pollution in Harbour and Coastal Sediments of Visakhapatnam, East Coast of India. Indian Journal of Marine Sciences, 23, 52-54.

[47] Barakat, A., El Baghdadi, M., Rais, J. and Nadem, S. (2012) Assessment of Heavy Metal in Surface Sediments of Day River at Beni-Mellal Region, Morocco. Research Journal of Environmental and Earth Sciences, 4, 797-806.

[48] Guo, W., Huo, S., Xi, B., Zhang, J. and Wu, F. (2015) Heavy Metal Contamination 
in Sediments from Typical Lakes in the Five Geographic Regions of China: Distribution, Bioavailability, and Risk. Ecological Engineering, 81, 243-255.

https://doi.org/10.1016/j.ecoleng.2015.04.047

[49] Szefer, P., Szefer, K., Glasby, G.P., Pempkowiak, J. and Kaliszan, R. (1996) Heavy Metal Pollution in Surficial Sediments from the Southern Baltic Sea off Poland. Journal of Environmental Science \& Health Part A, 31, 2723-2754. https://doi.org/10.1080/10934529609376520

[50] Lacerda, L.D. (1998) Trace Metals Biogeochemistry and Diffuse Pollution in Mangrove Ecosystems. ISME Mangrove Ecosystems Occasional Papers No. 2, 1-61.

[51] Shriadah, M.M.A. (1999) Heavy Metals in Mangrove Sediments of the United Arab Emirates Shoreline (Arabian Gulf). Water, Air, and Soil Pollution, 116, 523-534. https://doi.org/10.1023/A:1005139020681

[52] Ranjan, R.K., Ramanathan, A.L., Singh, G. and Chidambaram, S. (2008) Assessment of Metal Enrichments in Tsunamigenic Sediments of Pichavaram Mangroves, Southeast Coast of India. Environmental Monitoring and Assessment, 147, 389-411. https://doi.org/10.1007/s10661-007-0128-y

[53] de Vallejuelo, S.F.O., Arana, G., de Diego, A. and Madariaga, J.M. (2010) Risk Assessment of Trace Elements in Sediments: The Case of the Estuary of the Nerbioi-Ibaizabal River (Basque Country). Journal of Hazardous Materials, 181, 565-573. https://doi.org/10.1016/j.jhazmat.2010.05.050

[54] Stone, M. and Marsalek, J. (1996) Trace Metal Composition and Speciation in Street Sediment: Sault Ste. Marie, Canada. Water, Air, and Soil Pollution, 87, 149-169. https://doi.org/10.1007/BF00696834

[55] Zafra, C.A., Temprano, J. and Tejero, I. (2011) Distribution of the Concentration of Heavy Metals Associated with the Sediment Particles Accumulated on Road Surfaces. Environmental Technology, 32, 997-1008. https://doi.org/10.1080/09593330.2010.523436

[56] Adamiec, E., Jarosz-Krzemińska, E. and Wieszała, R. (2016) Heavy Metals from Non-Exhaust Vehicle Emissions in Urban and Motorway Road Dusts. Environmental Monitoring and Assessment, 188, 369.

https://doi.org/10.1007/s10661-016-5377-1

[57] Singh, A.K., Hasnain, S.I. and Banerjee, D.K. (1999) Grain Size and Geochemical Partitioning of Heavy Metals in Sediments of the Damodar River-A Tributary of the Lower Ganga, India. Environmental Geology, 39, 90-98.

https://doi.org/10.1007/s002540050439

[58] Chakraborty, P., Babu, P.V.R., Vudamala, K., Ramteke, D. and Chennuri, K. (2014) Mercury Speciation in Coastal Sediments from the Central East Coast of India by Modified BCR Method. Marine Pollution Bulletin, 81, 282-288.

https://doi.org/10.1016/j.marpolbul.2013.12.054

[59] Wang, S., Jia, Y., Wang, S., Wang, X., Wang, H., Zhao, Z. and Liu, B. (2010) Fractionation of Heavy Metals in Shallow Marine Sediments from Jinzhou Bay, China. Journal of Environmental Sciences, 22, 23-31.

https://doi.org/10.1016/S1001-0742(09)60070-X

[60] Lu, Y., Gong, Z., Zhang, G. and Burghardt, W. (2003) Concentrations and Chemical Speciations of $\mathrm{Cu}, \mathrm{Zn}, \mathrm{Pb}$ and $\mathrm{Cr}$ of Urban Soils in Nanjing, China. Geoderma, 115, 101-111. https://doi.org/10.1016/S0016-7061(03)00079-X

[61] Soto-Jiménez, M., Páez-Osuna, F. and Morales-Hernández, F. (2001) Selected Trace Metals in Oysters (Crassostrea iridescens) and Sediments from the Discharge Zone of the Submarine Sewage Outfall in Mazatlán Bay (Southeast Gulf of California): 
Chemical Fractions and Bioaccumulation Factors. Environmental Pollution, 114, 357-370. https://doi.org/10.1016/S0269-7491(00)00239-6

[62] Mwanamoki, P.M., Devarajan, N., Thevenon, F., Birane, N., De Alencastro, L.F., Grandjean, D., Mpiana, P.T., Prabakar, K., Mubedi, J.I., Kabele, C.G. and Wildi, W. (2014) Trace Metals and Persistent Organic Pollutants in Sediments from River-Reservoir Systems in Democratic Republic of Congo (DRC): Spatial Distribution and Potential Ecotoxicological Effects. Chemosphere, 111, 485-492.

https://doi.org/10.1016/j.chemosphere.2014.04.083

[63] Yang, Z., Wang, Y., Shen, Z., Niu, J. and Tang, Z. (2009) Distribution and Speciation of Heavy Metals in Sediments from the Mainstream, Tributaries, and Lakes of the Yangtze River Catchment of Wuhan, China. Journal of Hazardous Materials, 166, 1186-1194. https://doi.org/10.1016/j.jhazmat.2008.12.034

[64] Förstner, U., Ahlf, W. and Calmano, W. (1993) Sediment Quality Objectives and Criteria Development in Germany. Water Science and Technology, 28, 307-316. https://doi.org/10.2166/wst.1993.0629

[65] Ayyamperumal, T., Jonathan, M.P., Srinivasalu, S., Armstrong-Altrin, J.S. and Ram-Mohan, V. (2006) Assessment of Acid Leachable Trace Metals in Sediment Cores from River Uppanar, Cuddalore, Southeast Coast of India. Environmental Pollution, 143, 34-45. https://doi.org/10.1016/j.envpol.2005.11.019

[66] Nolting, R.F., Ramkema, A. and Everaarts, J.M. (1999) The Geochemistry of Cu, Cd, $\mathrm{Zn}, \mathrm{Ni}$ and $\mathrm{Pb}$ in Sediment Cores from the Continental Slope of the Banc d'Arguin (Mauritania). Continental Shelf Research, 19, 665-691. https://doi.org/10.1016/S0278-4343(98)00109-5

[67] Zhang, J. and Liu, C.L. (2002) Riverine Composition and Estuarine Geochemistry of Particulate Metals in China-Weathering Features, Anthropogenic Impact and Chemical Fluxes. Estuarine, Coastal and Shelf Science, 54, 1051-1070. https://doi.org/10.1006/ecss.2001.0879

[68] Reimann, C. and de Caritat, P. (2005) Distinguishing between Natural and Anthropogenic Sources for Elements in the Environment: Regional Geochemical Surveys versus Enrichment Factors. Science of the Total Environment, 337, 91-107. https://doi.org/10.1016/j.scitotenv.2004.06.011

[69] Haris, H. and Aris, A.Z. (2013) The Geoaccumulation Index and Enrichment Factor of Mercury in Mangrove Sediment of Port Klang, Selangor, Malaysia. Arabian Journal of Geosciences, 6, 4119-4128. https://doi.org/10.1007/s12517-012-0674-7 